Article

\title{
Granite Pavement Nitrate Desalination: Traditional Methods vs. Biocleaning Methods
}

\author{
Pilar Bosch-Roig ${ }^{1, *}$, Hugo Allegue ${ }^{2}$ and Ignacio Bosch ${ }^{3}$ (1) \\ 1 Instituto de Restauración del Patrimonio, Universitat Politècnica de València, 46022 Valencia, Spain \\ 2 Departamento de construcción y tecnologías arquitectónicas, Universidad Politécnica de Madrid, \\ 28040 Madrid, Spain \\ 3 Instituto de Tecnologías y Aplicaciones Multimedia, Universitat Politècnica de València, \\ 46022 Valencia, Spain \\ * Correspondence: pboschroig@gmail.com
}

Received: 28 June 2019; Accepted: 31 July 2019; Published: 5 August 2019

\begin{abstract}
High levels of nitrate contamination of granite stone are a major problem, affecting large surfaces of many historical monuments, particularly in the north-west of Spain. This study showed a comparison between different traditional and biotechnological desalination methods in order to evaluate the most appropriate cleaning treatment for nitrate desalination of granite. Three types of traditional desalination methods (with cellulose and/or sepiolite) were compared with two types of bacterial denitrifying treatments that used Pseudomonas stutzeri (with cotton wool or with agar $2 \%$ as delivery systems). The in-situ tests were carried in the Cristo Chapel of St ${ }^{a} \mathrm{M}^{\mathrm{a}}$ de Conxo in Santiago de Compostela (Spain), which has a high nitrate salt content in its granite pavement. Conductivity and nitrate content measurements, biological monitoring and digital image analysis were performed to determinate the efficacy of each method. The findings showed that both techniques succeeded in reducing salt content, but bio-desalination was the more effective method tested. This work contributes to the practical implementation of BTCH (Biocleaning Technologies for Cultural Heritage) for the bio-desalination of granite surfaces, and to the evaluation of the use of non-destructive cleaning techniques based on digital imaging.
\end{abstract}

Keywords: biocleaning; bio-desalination; bacteria; building materials; nitrate

\section{Introduction}

Soluble salt contamination is a very widespread problem found on cultural heritage monuments, cultural objects, contemporary buildings and civil constructions covering very large and diverse areas (pavements, walls, artistic structures and paintings). This salt action can cause important deterioration problems in the built-in materials due to the processes of crystallization/dissolution cycles of soluble salts. Salt efflorescence, blackening of surfaces, dissolution of the original materials, microcracks in the porous stone systems and the formation of crusts, among others, are some of the main problems related to salt contamination [1].

In order to reduce these deterioration effects in cultural heritage material, restorers, architects and conservators work on (i) stopping water intake, (ii) controlling the climatic conditions, and (iii) reducing the salt content present in the artistic materials.

Most of the affected buildings are religious monuments (churches, cathedrals, monasteries) in which obtaining of appropriate climatic conditions is almost impossible. Therefore, the only actions that can be achieved in this sense are directed at stopping water ingress (fixing roofs, isolating walls and pavements) and establishing ventilation conditions that favor the correct hygrothermal behavior of 
the interior of the building by installing systems to control temperature and humidity and controlling the opening of windows and doors when the building requires.

The origin of the salts can vary; they can come from the ground where the object is situated, from floods, they can be due to human additions (joint mortars for example), or be of geological or biological origin, or from wind or sea breezes, volcanic gas, or atmospheric contamination [2].

Salt content and deterioration are highly related to humidity; therefore, humid climates such as those in the north-west of Spain are much more severely affected than dry climates, such as those in the south-east.

The salt content and quantity that is potentially damaging to historical stone can be very variable. Salt can be found only on the surface or be affecting the interior, can affect only a small area or the entire historical entity. When large areas are affected, with variable salt content, damage normally occurs. The amount and type of salt present will be an important factor in determining the selection of the desalination method [3].

Desalination can be defined as the maximum possible reduction in the salt content present in a material by its extraction [2]. In order to reduce salt content in artistic materials, different intervention methods can be used. The most used are the traditional ones based on water-based poultices and plasters. Mechanical methods (ultrasound, microtome, scalpel, brush, vacuum), chemical methods (tensoactives, acids and alkalis, ionic exchange resins) and lasers are also used even if they are more aggressive to the substrate. Novel methods based on electro-kinetic desalination and biocleaning are starting to appear $[4,5]$.

Some of the most used traditional desalination methods are water-based poultices and plasters. They are usually composed of one or more hydrophilic materials (normally cellulose fibers) mixed with water. Sometimes absorbent clay minerals such as sepiolite are also added, and even Japanese paper between the poultice and the surface can be added in order to facilitate the poultice removal. Poultices can be applied directly to the stone or involve pre-wetting the stone surface before the application of the poultice [6]. The wet mix is placed on the top of the target surface for a period of time. Salts are extracted by a concentration difference (diffusion), by moisture flow (advection) or through gravity, pressure, temperature or density differences (convection) [7]. The salt ions are therefore transported from the surface into the poultice. The application time can vary from a few minutes to days, weeks or even months, where different applications are needed [8,9]. However, some researchers propose that the major salt extraction takes place in the first $10 \mathrm{~min}$, particularly when using cellulosic powder, and the poultice must be removed before the salts reflow from them back to the surface; the process can be repeated once the surface is completely dry [10]. These approaches are normally used when the object contains large amounts of salts, and procedures may involve successive poulticing that may affect the surface and will need extra care in the hands of expert conservator-restorers [3].

However, this type of desalination method is not risk-free; sometimes the effect of removing salts is more dangerous than leaving them in the monument. Some side effects related to changes in color (bleaching or staining), the movement of salts, salt formation, increased decay or excessive removal of original material can be observed. In addition, environmental and health risks can result when toxic solvents are added to the poultices and plasters [8,11,12].

Scientists differ on recommended poultice compositions and their efficiency in salt removal from stone. But most of them report that this is related to the characteristics of the stone (type of stone, pore network), the characteristics of the salts present (particularly salt solubility) and the type of desalination method used (contact with the surface, application time, temperature and humidity) $[6-8,13]$.

Despite being one of the biggest problems for the conservation of cultural heritage, and even after the development of a multitude of methods to avoid or minimize damage, the extraction of salts continues to be an unresolved problem due to the low efficiency or non-feasibility of desalination treatments.

Bio-desalination is one of the new developments of the biocleaning technologies for cultural heritage that is considered on this work. Biocleaning uses living microorganisms or their enzymes in 
order to remove undesired substances from artistic and non-artistic materials. It has shown itself to be an interesting alternative to traditional cleaning techniques, and has already been applied to many artistic monuments and artworks with successful results $[4,12,14-16]$. The results claim that biological techniques are safe, risk-free, non-invasive and very specific $[12,17]$. The optimal duration of treatment can vary from a few hours to one month $[18,19]$. Bacterial denitrification processes are characterized by the reduction of nitrate to nitrite and finally to molecular nitrogen or nitrogen oxides (gases), both aerobically and anaerobically. This ability is due to the presence in some bacterial species of nitrate and nitrite reductase enzymes.

Microorganisms used have to be non-pathogenic, non-sporulating and non-biodeteriogenic of the surfaces to be cleaned, and not presenting any risk to users or the artworks.

Some works have shown interesting removal of nitrate salts by using denitrifing bacteria. The first laboratory works were carried out with cells of Pseudomonas spp. and showed that they were able to remove nitrates from weathered calcareous stone and bricks [20]. Nitrate bioremoval from on-site sandstone materials was successfully performed in 2008 and 2011 on the walls of Matera cathedral (Italy) by removing $55 \%$ of nitrate content in $24 \mathrm{~h}$ treatment by direct application of Pseudomonas pseudoalcaligenes KF707 entrapped in Carbogel [15,21]. In 2013 Pseudomonas stutzeri 5190 in agar 2\% was used to remove $92 \%$ of nitrate efflorescence from frescoes on Santos Juanes church in València (Spain) [4]. Bioactive poultices of P. stutzeri were also used to reduce the nitrate content of model bricks [17]. Recently laboratory tests showed $60 \%$ nitrate content from salt efflorescence being remove from tuff stone samples by using Halomonas campaniensis sp., an extremophilic bacterium, in agar $2 \%$ [22]. Biological nitrate salt reduction on granite has not been reported on literature [23].

The evaluation of the success of a particular desalination method is another important point of the process. Most authors analyze salt extraction efficiency by calculating the relation of salt content before and after desalination treatments, related to the sample mass used [9]. This salt content analysis can be achieved by diverse methods, such as microscopy, conductivity analysis, ion chemical reactions, ion colorimetric reactions, X-ray diffraction, spectroscopy and ionic chromatography [24]. In order to calculate this value, there is a need to perform diverse destructive samplings on the surface being treated $[19,24]$. When artistic surfaces are studied, this invasive method is not recommended and in many cases is not possible to realize. Therefore, other non-destructive methods have to be proposed. Non-destructive ion conductivity techniques can be used to analyze the presence of salts on a surface after treatment $[25,26]$. When comparing different desalination methods, these surface ion conductivity values can give important information about the desalination processes, but, as previous studies have shown, large stone areas (e.g., pavements) normally show a non-homogeneous distribution of the salts. This should be taken into account because some of the differences in the results could be due to this variability rather than to the desalination treatment used. Therefore, another parameter should be analyzed in order to complement the results. Many authors use colorimetry for this purpose, studying the color changes after treatment [19]. Some authors have compared a digital camera with a spectrophotometer, showing its successful use as a non-contact colorimeter to measure the color of granite [26]. On the basis of this work, a novel digital imaging analysis tool is proposed as a non-destructive alternative to evaluate surface cleaning after desalination.

Considering the above, this research aims to compare the desalination ability of three traditional poultices based on cellulose and/or sepiolite, with bio-desalination using bioactive $P$. stutzeri poultices (with cotton wool or agar $2 \%$ ). To this end, different in-situ tests were applied for the reduction of nitrate content in the granite pavement of the Cristo Chapel of $\mathrm{St}^{\mathrm{a}} \mathrm{M}^{\mathrm{a}}$ de Conxo in Santiago de Compostela (Spain).

The $\mathrm{St}^{\mathrm{a}} \mathrm{M}^{\mathrm{a}}$ de Conxo Monastery original from the XII-century conserves a cloister with two Romanic arcs (with a 1129 foundational inscription). In the XVII-century, the Romanic church was demolished to construct a large one. The Cristo Chapel was enlarged between 1729-1743 by Simón Rodríguez. Nowadays the chapel has a Latin cross plan with a small nave, a crossing and a rectangular 
sanctuary. Altarpieces and sepulchres decorate it. The floor and the walls are made by granite masonry with mortar joints [27].

The floor of this chapel showed dark staining related to moisture and associated with high nitrate concentration in the surfaces. We used a complementary digital imaging tool in order to compare the success of the traditional and biological cleanings tested. To the best of our knowledge this is the first time that biological cleaning has been applied for nitrate salt reduction on in-situ granite and that digital imaging has been used to evaluate surface cleaning in order to complement desalination evaluation.

\section{Materials and Methods}

\subsection{Description of Site and Treated Areas}

Santa María de Conxo Monastery, sited in Santiago de Compostela, in the north-west of Spain, is a baroque complex of buildings (XVII-century), constructed over a XII-century church. The Cristo chapel is situated in the north-east of the complex. The chapel pavement, built totally of granite, is the object of this study (Figure 1).

Composed of $233 \mathrm{~m}^{2}$ of about $60 \times 40 \times 15 \mathrm{~cm}$ granite slabs covering the chapel ground, the pavement shows a darkening related to the high nitrate content. Previous hygroscopic studies showed that the high soluble salt content combined with the high humidity (mean values over $80 \%$ due to the particular microclimatic church environment) hinders the normal evaporation of the granite, resulting in this dark aspect because the hygroscopic salts retain water on the surface of the slabs. The city of Santiago de Compostela has a high level of air humidity most of the year (70, 80 and even $90 \% \mathrm{RH})$, which makes evaporation very difficult. Previous studies have claimed that an important reduction in salt content is needed to allow normal evaporation and correct drying of the slabs [27].

This research was carried out on two granite slabs in the south-west area of the chapel. One slab was used for assaying the traditional treatments, where 24 tests were carried out. The second slab was used for biological treatment, and 90 tests were performed.

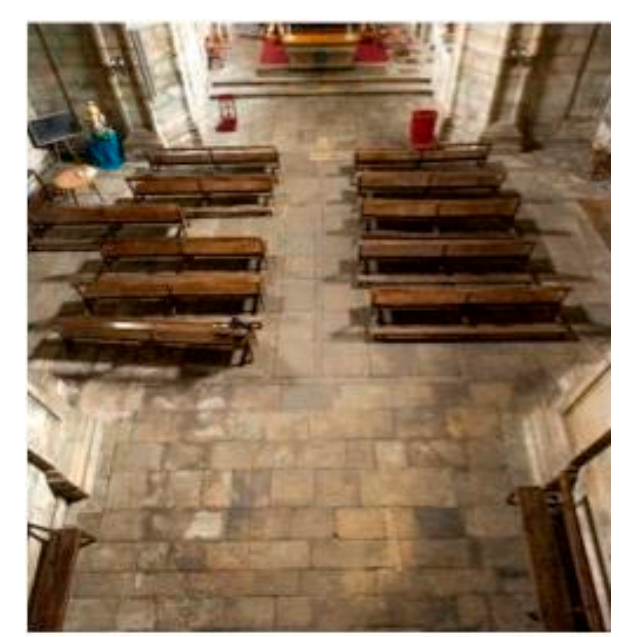

(a)

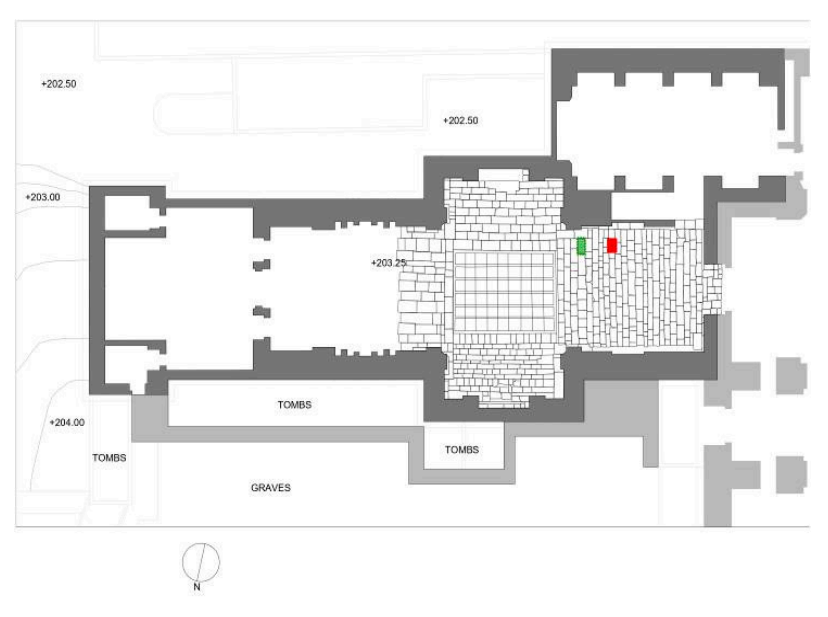

(b)

Figure 1. Cristo chapel of Santa María de Conxo Monastery: (a): General image of the chapel pavement and (b): The chapel plant (provided by Raquel Otero) showing the granite slabs; test areas are marked for the traditional tests (in green) and the biological tests (in red).

\subsection{Sampling and Material Characterisation}

Micro-samples were taken from the pavement with a steel scalpel, being as little invasive as possible. Samples were directly used for Fourier Transform Infrared (FTIR) spectroscopy and a little surface was scratched with a scalpel for photometric analysis in order to characterize the darkening of the granite surface and the soluble salt content. 
FTIR absorption spectra identification of inorganic compounds were obtained using a Vertex 70 (Bruker Optics) Fourier-transform spectrometer with FR-DTGS (fast recovery deuterated triglycine sulphate) temperature-stabilized coated detector an MKII Golden Gate Attenuated Total Reflectance (ATR) accessory. Thirty-two scans were collected at a resolution of $4 \mathrm{~cm}^{-1}$.

Photometric analyses of soluble salt content used a NV201 photometer (Optika, Ponteranica, Italy). Micro-samples (0.3-0.4 g) were pulverized, $10 \mathrm{~mL}$ of deionized water added and submerged in an ultrasonic bath for $20 \mathrm{~min}$. Samples were then centrifuged and the supernatant used for analyzing three ions: Chloride $\left(\mathrm{Cl}^{-}\right)$, sulphate $\left(\mathrm{SO}_{4}{ }^{2-}\right)$ and nitrate $\left(\mathrm{NO}_{3}{ }^{-}\right)$.

\subsection{Bacterial Growth and Culture Methods}

Nitrate-reducing bacterium P. stutzeri, strain 5190 (DSMZ) was selected. Bacteria were inoculated overnight at $28^{\circ} \mathrm{C}$ for $48 \mathrm{~h}$ in Nitrate Broth culture $1000 \mathrm{~mL}$ flask. Suspensions containing approx. $10^{7}$ colony forming units (CFU) $\mathrm{mL}^{-1}$ of exponentially growing bacteria were obtained and centrifugated (4200 rpm for $10 \mathrm{~min}$ ). The pellet was washed twice with $\mathrm{NaCl} 0.8 \% \mathrm{pH} 7.0$ and re-suspended in $50 \mathrm{~mL}$ mineral water. The final cell concentration obtained was about $10^{10} \mathrm{CFU} \mathrm{mL}{ }^{-1}$; the suspension was sent by $24 \mathrm{~h}$ refrigerated courier at $2-4{ }^{\circ} \mathrm{C}$ to the church for application, or alternatively stored at $4{ }^{\circ} \mathrm{C}$ for a few days.

\subsection{Traditional Treatments In-Situ Desalination Tests}

According to most commonly used plasters described in the literature [6-8,13], two materials have been chosen to prepare traditional desalination methods based on water-based poultices and plasters: Cellulose Arbocell BC-200 (Kremer Pigmente) fiber length $300 \mu \mathrm{m}$ and width $20 \mu \mathrm{m}$ ) as hydrophilic material, and sepiolite Pansil 100 (CTS, España, granulometry 35\% <38 $\mu \mathrm{m}, 35 \%>125 \mu \mathrm{m}$, and 4\% $250 \mu \mathrm{m})$ as absorbent clay.

Different contact times, poultices and number of applications were assayed on site. Three types of poultice were prepared (deionized water was added to achieve good consistency and adherence): Pure cellulose (C) (120 mL of $\mathrm{H}_{2} \mathrm{O}$ to $40 \mathrm{~g}$ of cellulose), pure sepiolite (S) ( $155 \mathrm{~mL}$ of $\mathrm{H}_{2} \mathrm{O}$ to $130 \mathrm{~g}$ of sepiolite) and 1:1 cellulose-sepiolite mixture (CS) $\left(110 \mathrm{~mL}\right.$ of $\mathrm{H}_{2} \mathrm{O}$ to $25 \mathrm{~g}+25 \mathrm{~g}$ of cellulose and sepiolite). Different contact times were tested: $10 \mathrm{~min}$ (10), $24 \mathrm{~h} \mathrm{(24)}$ and $144 \mathrm{~h} \mathrm{(144),} \mathrm{and} \mathrm{different} \mathrm{numbers} \mathrm{of}$ application: 1, 3 or 9. Table 1 and Figure 2 show the six different on-site traditional poultices tests applied (dimensions: $80 \times 80 \times 5 \mathrm{~mm}$ ). Between applications a period of $24 \mathrm{~h}$ was allowed for the surface to dry before the next treatment. All tests were carried out in triplicate and six control areas were left with no treatment. In order to homogenize the test results, all tests were performed using a mold.

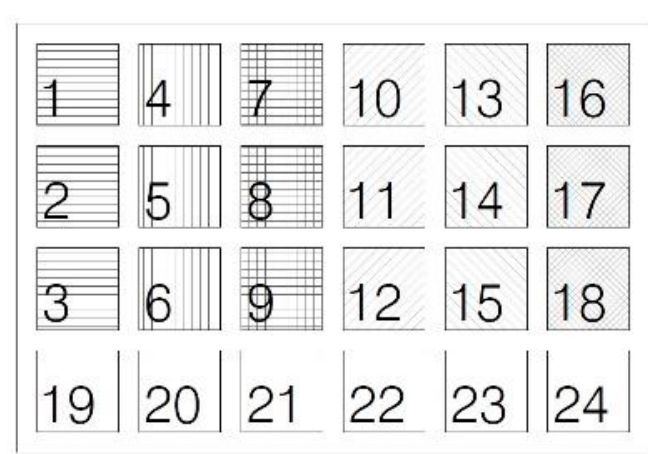

(a)

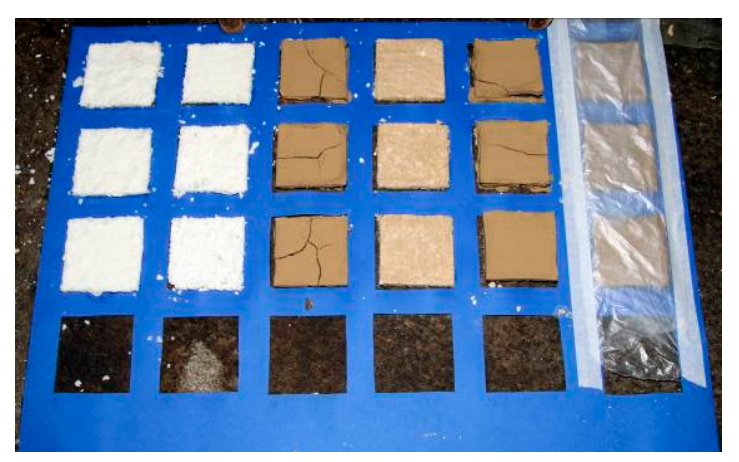

(b)

Figure 2. Traditional treatments assayed: (a): Scheme of the 18 test assayed (C10: 1, 2, 3; C24: 4, 5, 6; C10 + S24: 7, 8, 9; CS24: 10, 11, 12; S24: 13, 14, 15; SP144: 16, 17, 18; control: 19, 20, 21, 22, 23, 24) (b): Image of the treatments applied on site. 
Table 1. Description of the traditional poultices assayed on site.

\begin{tabular}{cccc}
\hline Test Name & Material & Number of Applications & Application Time \\
\hline C10 & Cellulose & 9 & $10 \mathrm{~min}$ \\
C24 & Cellulose & 3 & $24 \mathrm{~h}$ \\
S24 & Sepiolite & 3 & $24 \mathrm{~h}$ \\
CS24 & Cellulose-sepiolite & 3 & $24 \mathrm{~h}$ \\
C10 + S24 & Cellulose-sepiolite & 3 & $10 \mathrm{~min}+24 \mathrm{~h}$ \\
SP144 & Sepiolite + plastic film & 1 & $144 \mathrm{~h}$ \\
\hline Control & No treatment & - & - \\
\hline
\end{tabular}

\subsection{Biological Treatments In-Situ Desalination Tests}

P. stutzeri 5190 DSMZ (B) was selected as the bio-desalination agent and two delivery systems were assayed: Cotton wool (W) and agar-agar $2 \%(\mathrm{~A})$.

Different contact times were tested: $3 \mathrm{~h}, 24 \mathrm{~h}, 48 \mathrm{~h}$ and $72 \mathrm{~h}$, with only one application. Table 2 shows the different on-site biocleaning tests applied (dimensions: $30 \times 30 \times 5 \mathrm{~mm}$ ). All tests were carried out in triplicate and two controls were used: With no treatment (control) and with the delivery system but without bacteria (CA and CW).

The bacterial suspension was applied directly onto the study surface with a brush, agar or cotton wool was then placed on top of it and the temperature maintained at $25 \pm 4{ }^{\circ} \mathrm{C}$ during the treatment time by using infrared heat lamps to ensure the correct metabolic activity of the bacteria. After treatment, the carriers (agar or cotton wool) were removed and the surface cleaned using a sponge and sterile deionized water to avoid leaving bacteria or carrier rests that could damage the slabs. The painted surface was let dry at ambient temperature.

Table 2. Description of the bio-desalination treatments assayed on site.

\begin{tabular}{cccc}
\hline Test Name & Material & Number of Applications & Application Time (h) \\
\hline BA & P. stutzeri + agar & 1 & $3,24,48,72$ \\
BW & P. stutzeri + cotton wool & 1 & $3,24,48,72$ \\
CA & Control agar & 1 & $3,24,48,72$ \\
CW & Control cotton wool & 1 & $3,24,48,72$ \\
Control & No treatment & - & - \\
\hline
\end{tabular}

\subsection{Digital Analysis of Cleaning}

The cleaning (reduction in dark staining) of the in-situ tests was estimated by digital image analysis. Digital images were taken before and after the treatments. In order to standardize the images, a tripod with a fixed condition (ISO100, f/8.0, 1/250 s, focal length $19 \mathrm{~mm}$ ) digital camera (Canon EOS $50 \mathrm{D}$ ) was used. In order to facilitate the digital image processing, a template of blue cardboard surrounding the test area was used (see Figures 2 and 3).

For digital image analysis, a specific software scheme and method was developed in MatLab matrix programming environment (see Figure 4). 

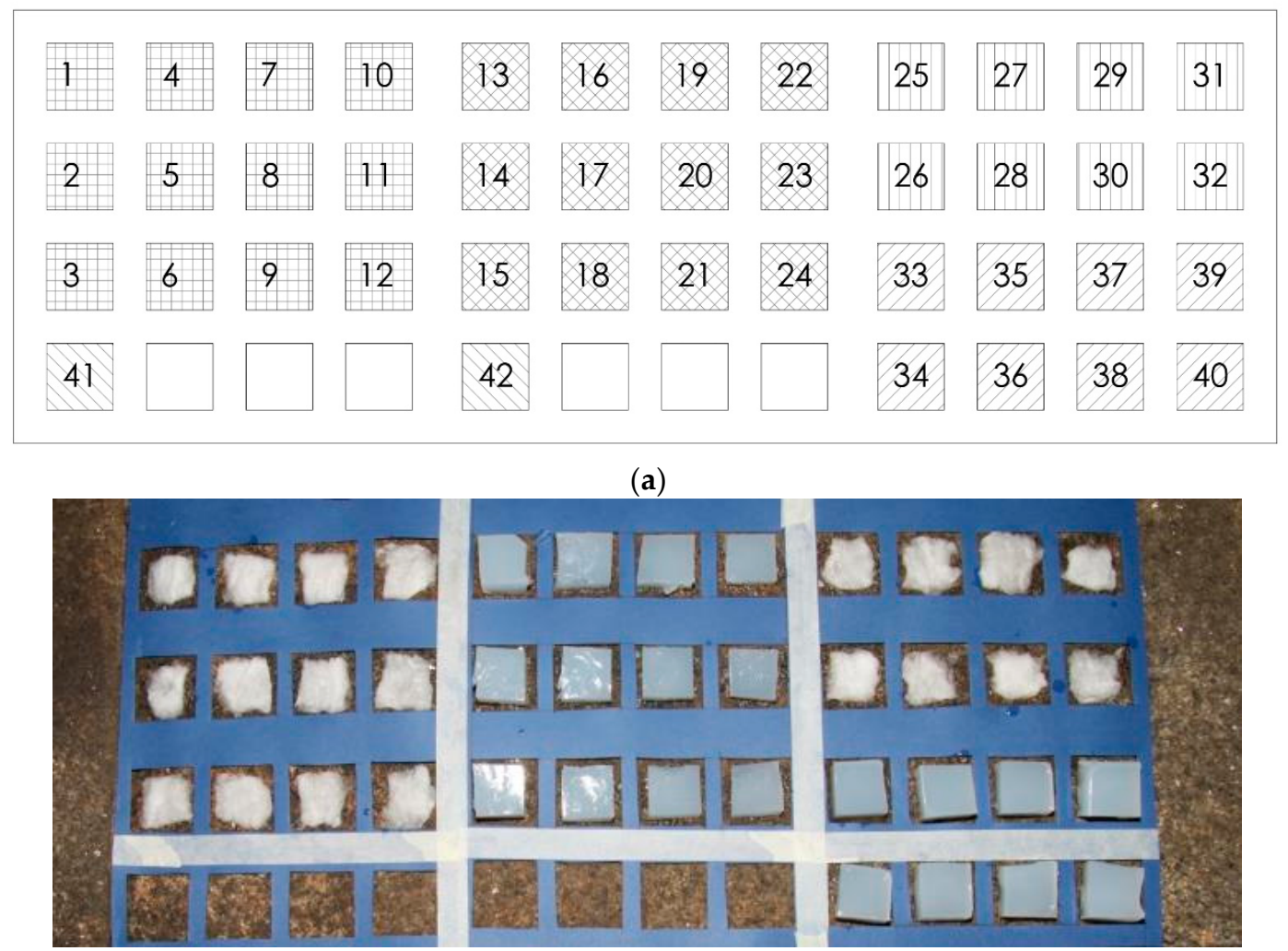

(b)

Figure 3. Biological treatments assayed: (a): Scheme of the 42 test assayed (BW: 1-12; BA: 13-24; CW: 25-32; CA: 33-40; Control: 41-42; Treatment times: 3 h: 1-3, 13-15, 25, 27, 33, 34; 24 h: 4-6, 16-18, 26, 28, 35, 36; 48 h: 7-9, 19-21, 29, 30, 37, 38; 72 h: 10-12, 22-24, 31, 32, 39, 40) (b): Image of the treatments applied on site.

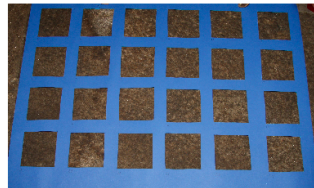

image before treatment

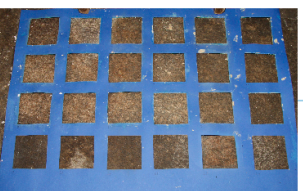

image after treatment

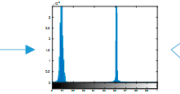

HSV Threshold

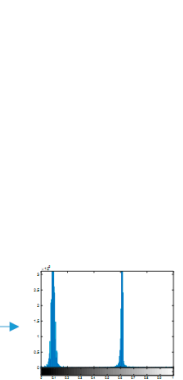

HSV Threshold

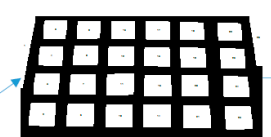

mask and bwlabel

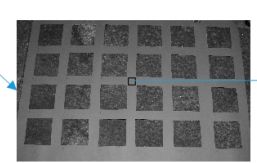

grey image
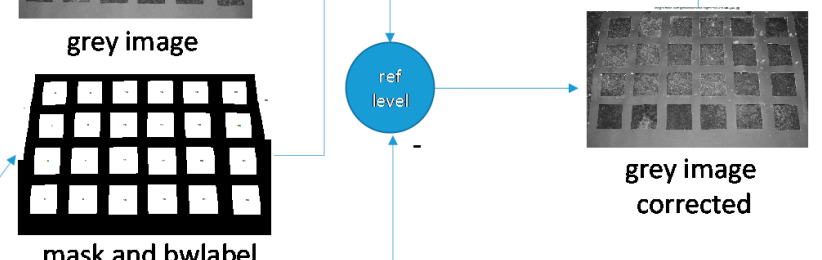

grey image

corrected

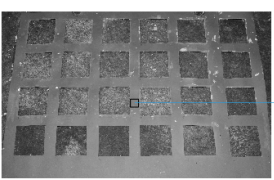

grey image

Figure 4. Digital image analysis scheme.

Specifically, image analysis involved a first stage of organizing the results of the photographic control to facilitate processing, selecting the before-and-after images of each treatment. Subsequently, a segmentation of each test area was carried out using morphological processing, obtaining their 
masks, numbering and location, in order to determine and store the pixels that made up each test area in a results structure. Next, the grey levels of each pixel of each test area were analyzed and quantified, selecting a number of pixels common to each test area to analyze the pixels that could be representative and comparative between tests. A luminosity correction of the images was carried out to homogenize the test areas between the images before and after the treatment. Finally, the results obtained were shown by means of different graphical representations. Median, standard deviation and outliers of each test area were calculated for each treatment replica (three test areas/replica/treatment). Comparative results were determined by calculating the differences in grey value before and after each treatment, compensating for the control median value.

\subsection{Monitoring of Desalination}

The ionic conductivity of each type of poultice was estimated before and after their application with a conductivity meter (Consort C830, Consort bvba, Belgium). Ionic conductivity was measured by direct contact of the conductivity meter with the poultices. The conductivity was also measured after treatment by applying a small cellulose plaster with deionized water ( $3: 1 \mathrm{wt} / \mathrm{wt})$ for $24 \mathrm{~h}$, removal from the surface and allowing to dry. Deionized water (4 times the weight of the cellulose) was then added to the cellulose plaster placed in a petri dish and conductivity was measured by direct contact [10]. The conductivity was also measured of the deionized water used $(8.2 \mu \mathrm{S} / \mathrm{cm})$, sepiolite $(12 \mu \mathrm{S} / \mathrm{cm})$ and cellulose $(17 \mu \mathrm{S} / \mathrm{cm})$, arbocel $(18 \mu \mathrm{S} / \mathrm{cm})$ and agar $2 \%(20 \mu \mathrm{S} / \mathrm{cm})$; these values were subtracted from the test data to allow a real comparison between the different methods. Each ion conductivity measures were done in triplicate.

Nitrate content of the stone before and after treatments was estimated by using semi-quantitative colorimetric nitrate-nitrite tests (Quantofix, Macherey-Nagel, Düren, Gemany) carried out directly on the granite surface moistened with $1 \mathrm{~mL}$ of deionized water applied on a thin cellulose paper.

\subsection{Monitoring of Bacterial Viability}

For monitoring bacterial viability used in the bio-desalination treatment, colony counts were made before sending the bacteria and after $72 \mathrm{~h}$ in the freezer to simulate the travel conditions and the bacterial survival ratio (BSR) calculated. The BSR was calculated as the ratio of the log of the number of bacterial cells present in the suspension after travel (A) to the log of the number of viable cells before travel (B) multiplied by 100 , i.e., $B S R=\left(\frac{\log (A)}{\log (B)}\right) \times 100$ [28].

In order to monitor bacterial and fungi presence on the treated surface, contact plates with nutrient agar and sabouraud chloramphenicol agar (respectively) were taken before and after the biological treatments. The plates were incubated at $28^{\circ} \mathrm{C}$ for $48 \mathrm{~h}$ for bacteria and 5 days for fungi and colonies were counted and expressed in CFU per analyzed area $\left(25 \mathrm{~cm}^{2}\right)$.

\subsection{Statistical Analysis}

Data obtained were analyzed by calculating, mean, median and standard deviation. Analysis of variance (ANOVA) was also used in order to evaluate statistically significant differences between the different treatments applied. The results of are shown by $p$-values $<0.05$.

\section{Results}

\subsection{Salt Composition of the Granite Pavement Surfaces}

The main chemical composition of the pavement obtained by FTIR analysis (Figure 5) was quartz $\left(1161 \mathrm{~cm}^{-1}, 1087 \mathrm{~cm}^{-1}, 793 \mathrm{~cm}^{-1}, 776 \mathrm{~cm}^{-1}, 693 \mathrm{~cm}^{-1}\right)$, feldspar $\left(1055 \mathrm{~cm}^{-1}, 1161 \mathrm{~cm}^{-1}, 1001 \mathrm{~cm}^{-1}\right.$, $\left.939 \mathrm{~cm}^{-1}, 758 \mathrm{~cm}^{-1}, 744 \mathrm{~cm}^{-1}, 646 \mathrm{~cm}^{-1}\right)$, calcite $\left(1425 \mathrm{~cm}^{-1}, 876 \mathrm{~cm}^{-1}, 712 \mathrm{~cm}^{-1}\right)$, Kaolinite group minerals $\left(3693 \mathrm{~cm}^{-1}, 3619 \mathrm{~cm}^{-1}, 911 \mathrm{~cm}^{-1}\right)$ correlating with granite stone. Infrared spectra also showed 
the presence of gypsum $\left(3484 \mathrm{~cm}^{-1}, 3400 \mathrm{~cm}^{-1}, 1618 \mathrm{~cm}^{-1}, 1684 \mathrm{~cm}^{-1}, 1484 \mathrm{~cm}^{-1}, 1119 \mathrm{~cm}^{-1}, 607 \mathrm{~cm}^{-1}\right)$ probably from the grout mortar. Peaks characteristic of nitrate $\left(1356 \mathrm{~cm}^{-1}\right)$ were also found.

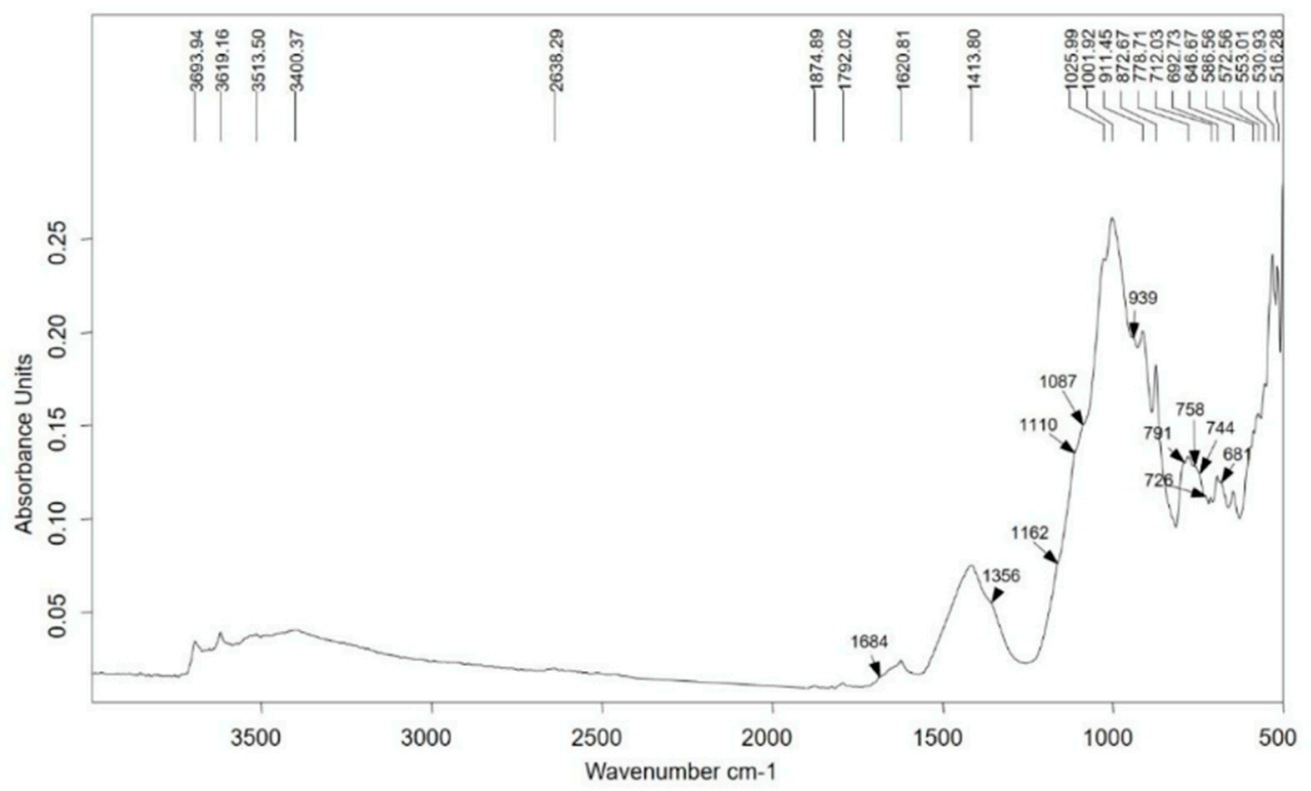

Figure 5. Infrared absorbance spectrum showing the presence of siliceous minerals and nitrate salts on the pavement surface.

Photometric analysis of the soluble salt content of the granite pavement found mostly nitrates (50-60\%) but there were also some sulphates (37-26\%) and chlorides (12-17\%).

Semi-quantification of the nitrate and sulphate salt content of the pavement surface by ion chromatography of nitrate and sulphate tests strips (Quantofix) showed values of $>500 \mathrm{ppm}$ and $<200$ ppm, respectively.

\subsection{In-Situ Desalination Tests}

\subsubsection{Traditional Desalination Methods}

All the traditional poultices tested (described in Section 2.3) showed a cleaning effect on the slab by visual inspection (Figure 6).

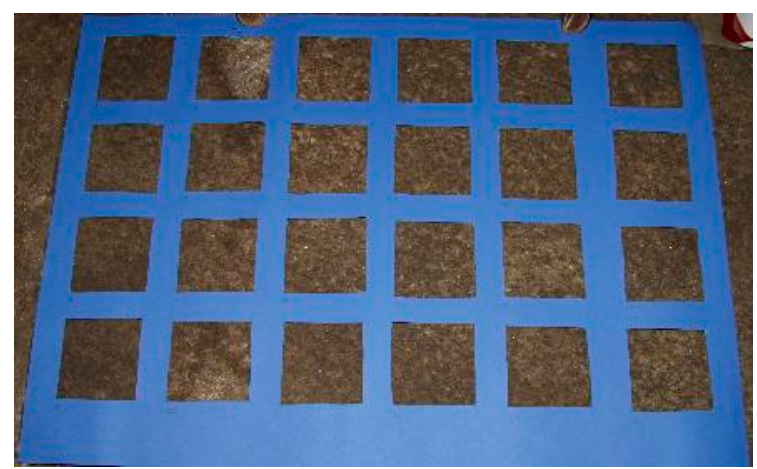

(a)

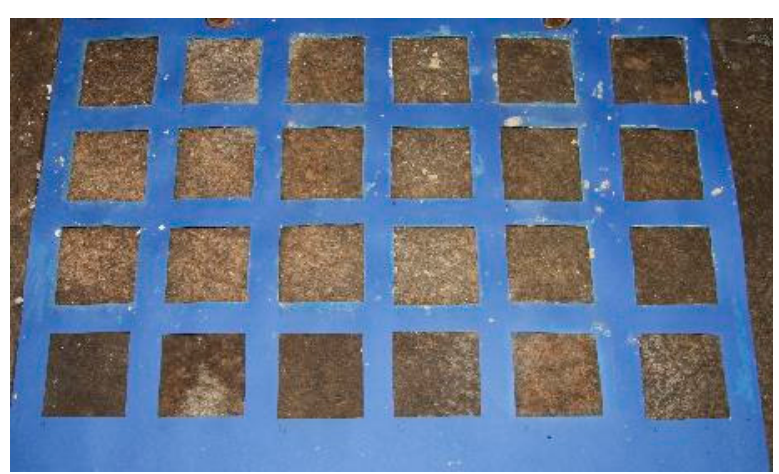

(b)

Figure 6. Image detailing the surface test areas: (a) Before any treatment; (b) after the traditional treatments.

Salt contents of the poultices after each application were analyzed by direct measurement of ion conductivity, giving information about the salts absorbed by the plasters, which can be related to their extraction capacity (Figure 7). All poultices showed the highest salt absorption on their first application 
(Figure 7, blue color), $\mathrm{C} 10+$ S24 being the one with highest first salt absorption and C10 the one with the lowest first salt absorption. Even though the salt absorption by $\mathrm{C} 10$ in the first application was the lowest, when applied three times the sum of salts absorbed was higher than that obtained using a cellulose plaster for $24 \mathrm{~h}$ (C24) or cellulose and sepiolite for $24 \mathrm{~h}$ (CS24). When applying C10 for nine applications, the sum of salts absorbed was the highest.

These results agree with authors who state that the highest salt extraction when using cellulose poultices is achieved in the first $10 \mathrm{~min}$ of treatment (studies done on sedimentary rocks) [10]. When comparing salt absorbed in one application with sepiolite for $24 \mathrm{~h}$ (S24) or for $144 \mathrm{~h}$ (SP144) no significant differences were seen, indicating that in this particular case, times over $24 \mathrm{~h}$ do not augment salt absorption. This could be explained by the salts having reached desalination equilibrium or because these types of poultice cannot extract more salts due to their porosity, adsorption capacity or substrate contact area, reaching maximum salt extraction capacity after $24 \mathrm{~h}$ of treatment. Salt absorption shows a decrease on successive applications in all cases, indicating that the salt poultices are reaching their maximum salt extraction capacity.

When comparing the total salt absorbed by the different poultices (Figure 7 and Table S1, sum of all colors), treatments C24 and CS24 showed very similar salt absorptions after three applications (means not significantly different), showing that the addition of sepiolite to the poultice does not seem to increase the amount of salt absorbed. The same is seen when comparing sepiolite alone (S24) with sepiolite and a prior application of cellulose for $10 \mathrm{~min}(\mathrm{C} 10+\mathrm{S} 24)$, which showed a slight increase in salt absorption but with means not significantly different. These results agree with other studies by Carretero et al. 2006, who applied sepiolite-cellulose plasters to desalinate sandstone and observed no relationship between plaster composition and salt removal ability, concluding that it is more related to the specific salts present in the stone and to the stone porosity, composition, homogeneity and pore network [7].

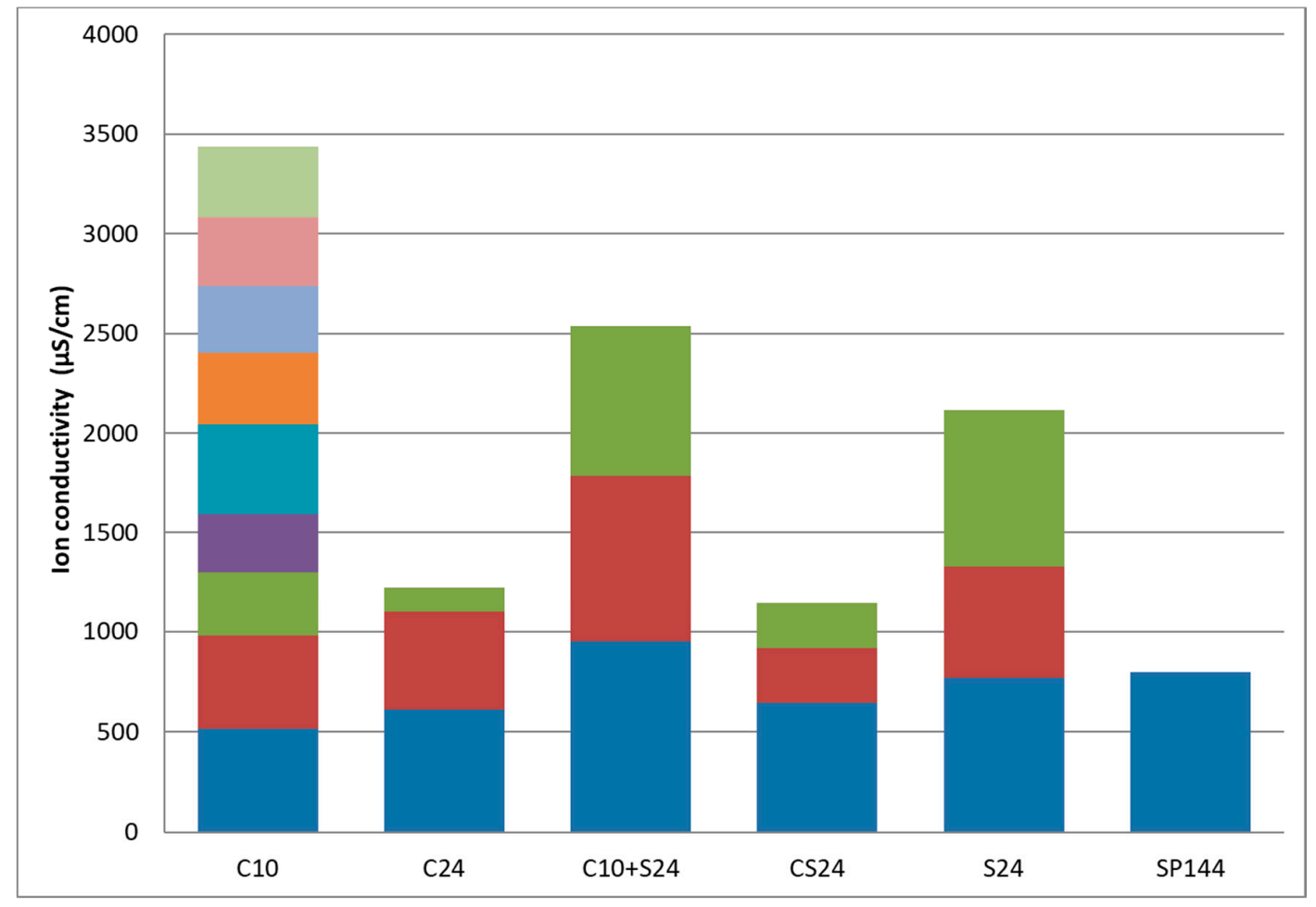

Figure 7. Ion conductivity mean results of different poultices (C: Cellulose, S: Sepiolite, SP: Sepiolite and plastic film); contact times (10: $10 \mathrm{~min}, 24: 24 \mathrm{~h}, 144: 144 \mathrm{~h}$ ); and applications (blue: First, red: Second, green: Third, purple: Fourth, turquoise: Fifth, orange: Sixth, blue-purple: seventh, rose: Eighth, pale green: Ninth). 
In order to check whether the mass of the poultice is a critical factor in desalination, a mass-conductivity analysis of the different poultices applied was carried out. The results show no linear correlation between mass and ion conductivity (Figure 8), indicating that salt absorption is independent of the mass of the poultices used. This result agrees with other authors, who suggest that the ion conductivity must be related to the surface area but not to the mass of the poultice used [29]. Therefore, extraction efficiency must be dependent mostly on the material used for the poultice, the contact surface and the application times.

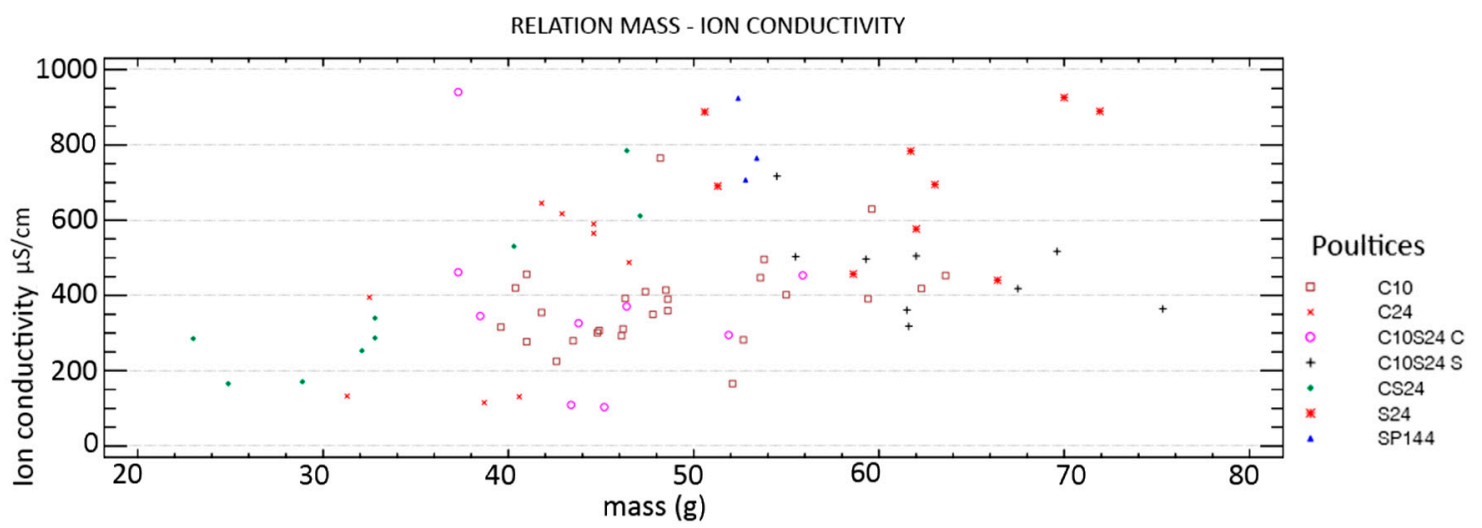

Figure 8. Relation between poultice mass and ion conductivity for the different traditional treatments assayed.

After desalination treatments, ion conductivity of the cleaned surfaces was measured in triplicate. Mean values shown in Table 3 indicate that C24, C10 + S24 and CS24 showed the lowest levels of salts remaining on the surface of the pavement after treatment, followed very closely by C10. Higher levels of salts remaining were seen after S24 and SP144 treatments, with conductivity values similar or even higher than those of the control areas (with no treatment). When analyzing statistically the three treatments with the lowest levels of salts remaining (C24, C10 + S24 and CS24), the means were not significantly different, indicating that the presence of salts on the surface of the slab after treatment were equivalent. High values seen on the surface after S24 and SP144 treatments could be due to salt mobilization to the surface by the sepiolite poultices.

Table 3. Mean ion conductivity values of the traditional desalination treatments assayed.

\begin{tabular}{ccc}
\hline Traditional Treatments & Ion Conductivity Mean $(\mu \mathrm{S} / \mathrm{cm})$ & Standard Deviation $(\mu \mathrm{S} / \mathrm{cm})$ \\
\hline C10 & 352.33 & 71.81 \\
C24 & 126.33 & 9.87 \\
C10 + S24 & 137.33 & 54.35 \\
CS24 & 225.67 & 99.05 \\
S24 & 529.67 & 139.95 \\
SP144 & 798.67 & 112.35 \\
Control & 550.00 & 50.00 \\
\hline
\end{tabular}

When analyzing the cleaning levels of the different treated areas by digital analysis, and adjusting all the values to the control median (with no treatment) (Figure 9), the traditional treatments with the best cleaning results (with the greatest differences before and after treatment compared with control area) were CS24, C24, C10 and C10 + S24, which mostly agrees with the ion conductivity results after traditional desalination. In treatments based on sepiolite only (S24 and SP144) very slight differences can be seen compared to control areas, showing very poor cleaning (see Figure 9), agreeing with results obtained on ion conductivity levels on the surface, which were very similar or even higher than the control areas (see Table 3). 


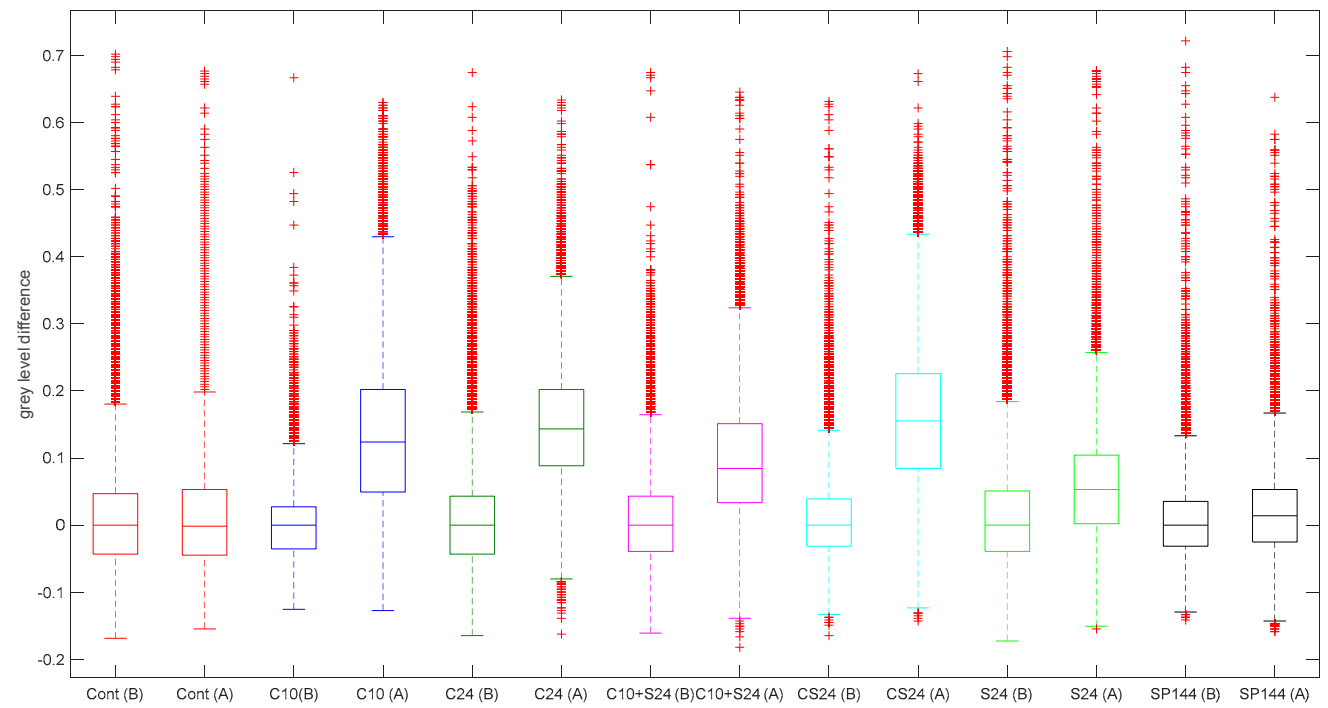

Figure 9. Boxplot showing median, standard deviation and outliers of the different traditional treatments assayed, adjusting all the values with the control median before treatment. From left to right in before (B)-and-after (A) treatment pairs: Control, C10, C24, C10 + S24, CS24, S24 and SP144.

Even though ion conductivity showed a reduction in salt content and digital image analysis showed a reduction in the grey levels of the surface with the traditional treatments tested, semi-quantitative nitrate colorimetric tests (Quantofix) analysis on the test surfaces before (500 ppm) and after (500 ppm) desalination did not show changes in the levels of nitrate. This could be because the nitrate content of the pavement was higher than the sensitivity of the method (0-500 ppm).

\subsubsection{Biological Methods of Nitrate Desalination}

Diverse biocleaning treatments using P. stutzeri $\left(25 \pm 4{ }^{\circ} \mathrm{C}\right)$ were applied in-situ in small areas deteriorated by nitrate salts in order to determine the best bio-desalination protocol. After biological treatments (described in Section 2.4), visual inspection of the slab showed a cleaner surface (Figure 10b) with no damage to the stone surface. Periodical visual monitoring showed that the tested areas remained clean three years after the applications.

Ion conductivities of the cleaned surfaces were measured in triplicate for each test. Mean values shown in Table 4 indicate that bacterial treatments with agar $2 \%$ showed lower levels of salts remaining on the surface of the pavement after treatment than did bacterial treatments using cotton wool. The lowest surface ion conductivity was found after $48 \mathrm{~h}$ of treatment. Areas where control tests of both delivery systems were applied (without bacteria) showed the highest mean surface ion conductivity values: $86.40 \mu \mathrm{S} / \mathrm{cm}$ for agar $2 \%$ with deionized water and $181.00 \mu \mathrm{S} / \mathrm{cm}$ for cotton wool with deionized water. However, when compared to untreated areas $(550 \mu \mathrm{S} / \mathrm{cm})$, a reduction of salt content was found.
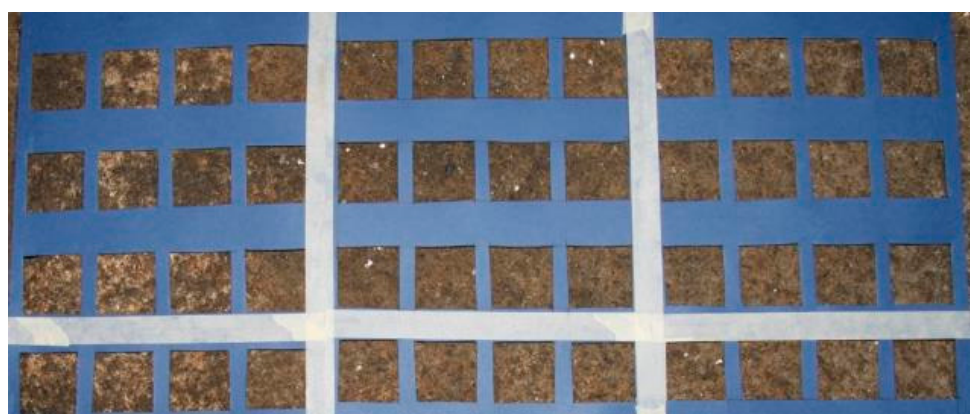

(a)

Figure 10. Cont. 

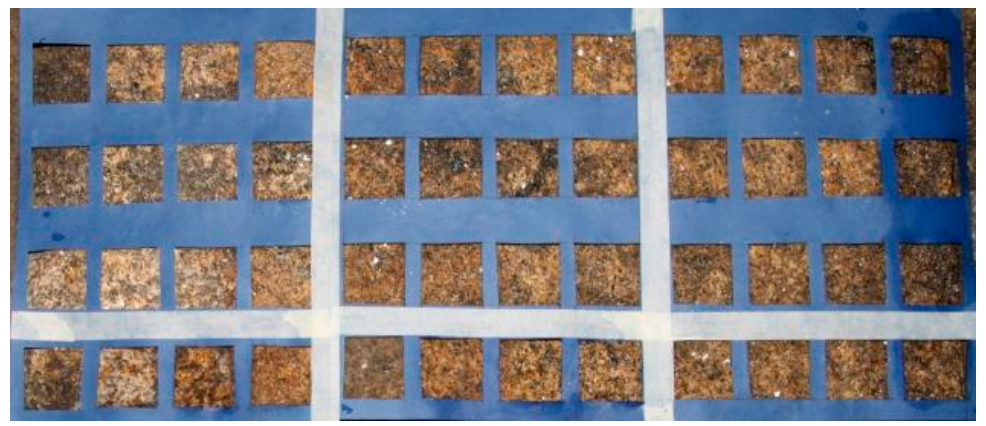

(b)

Figure 10. Images detailing the surface test areas: (a) Before treatment; (b) after biological treatments and controls assayed.

Table 4. Mean ion conductivity values of the biological desalination treatments assayed.

\begin{tabular}{cccc}
\hline Biological Treatments & Treatment Time $(\mathbf{h})$ & Ion Conductivity Mean $(\boldsymbol{\mu S} / \mathbf{c m})$ & Standard Deviation $(\boldsymbol{\mu S} / \mathbf{c m})$ \\
\hline BA $^{1}$ & 3 & 52.60 & 11.52 \\
BA $^{1}$ & 24 & 49.13 & 9.97 \\
BA $^{1}$ & 48 & 48.73 & 7.21 \\
BA $^{1}$ & 72 & 64.26 & 20.01 \\
BW $^{2}$ & 3 & 100.26 & 35.26 \\
BW $^{2}$ & 24 & 96.13 & 16.26 \\
BW $^{2}$ & 48 & 137.00 & 31.76 \\
BW $^{2}$ & 72 & 173.26 & 65.72 \\
Control & - & 550.00 & 50.00 \\
\hline
\end{tabular}

${ }^{1}$ BA: Bacterial treatment with agar $2 \% .{ }^{2}$ BW: Bacterial treatment with cotton wool. -: Not applicable.

Semi-quantitative colorimetric nitrate tests (Quantofix) analysis of the test surfaces before and after bio-desalination showed important reductions in nitrate content after $48 \mathrm{~h}$ of treatment. This surface salt reduction was higher for the biological treatments applied with agar 2\% (100 ppm) than those with cotton wool (200 ppm). Neither control treatment: Agar $2 \%$ without bacteria (500 ppm) or cotton wool without bacteria (500 ppm), showed detectable nitrate salt reduction.

Digital analysis of the median differences showed better cleaning by both delivery systems when applying bacteria compared with the controls (delivery systems without bacteria). With respect to treatment time, an increase in cleaning with time can be seen up to a maximum after $48 \mathrm{~h}$ treatment in both cases (Figure 11).

Even though ion conductivity and nitrate content on the surface showed lower values in areas treated with P. stutzeri and agar 2\% (BA) compared to P. stutzeri and cotton wool (BW), digital analysis showed higher cleaning percentages after BW than after BA (Figure 12a), showing that there is no direct relation between salts remaining on the surface and the appearance of the cleaned surface.

When analyzing the cleaning level of the different bio-cleaned areas by digital analysis, after adjusting all values with the control median (delivery systems without bacteria), biological treatments showed in all cases a cleaner surface (compared with control areas), $48 \mathrm{~h}$ treatment with P. stutzeri with agar $2 \%$ or with cotton wool showing the cleanest areas (Figure $12 b$ ). 


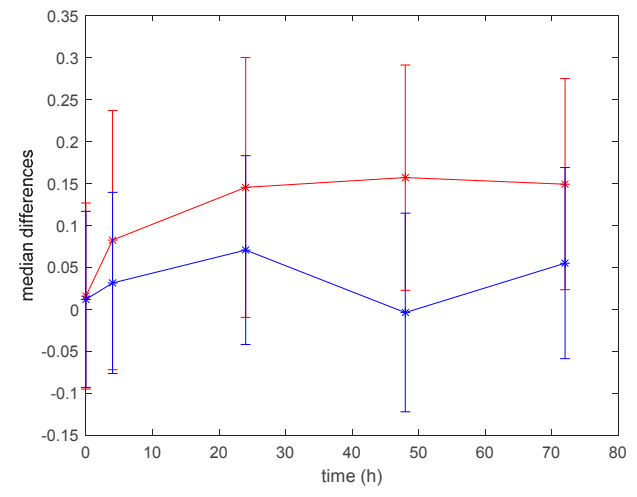

(a)

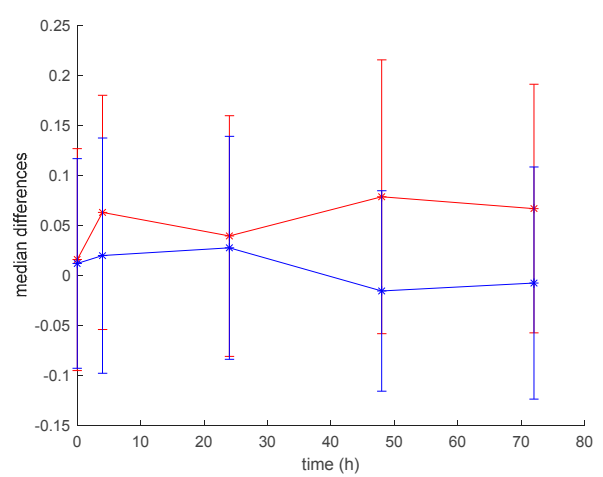

(b)

Figure 11. Digital analysis of median differences of the biological treatments (upper, red) and their controls without bacteria (lower, blue): (a) Using cotton wool as delivery system; (b) using agar $2 \%$ as a delivery system.

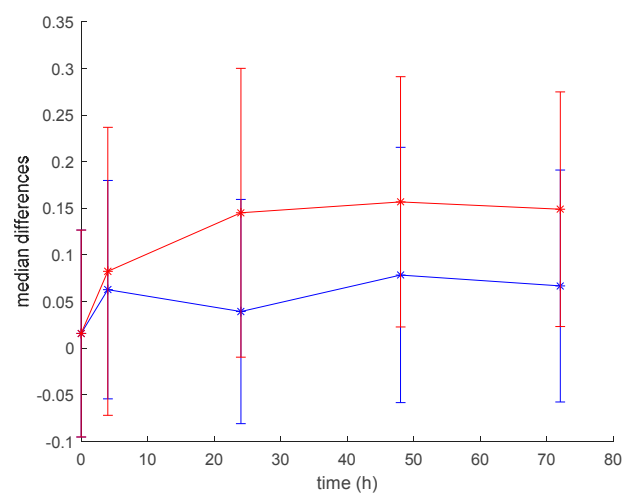

(a)

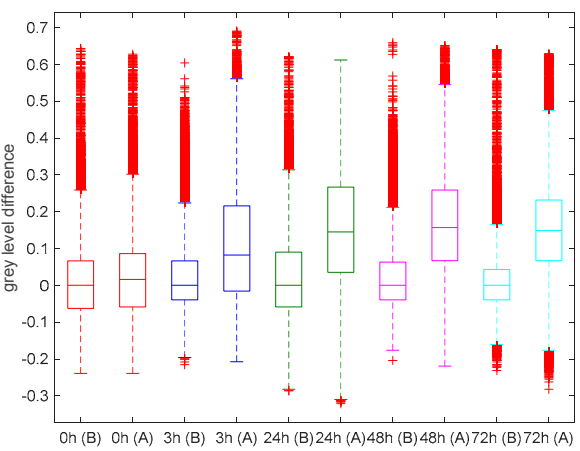

(b)

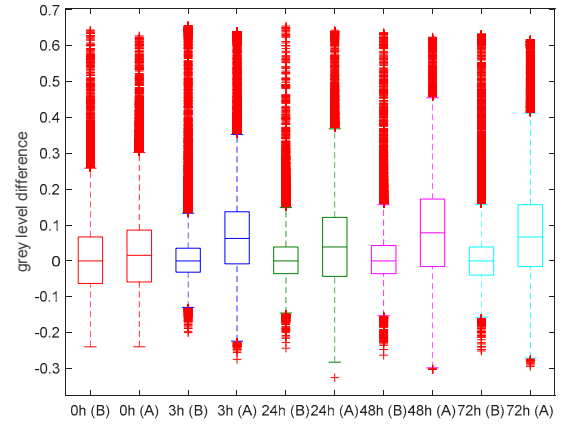

(c)

Figure 12. Digital analysis values of the biological cleaning treatments: (a) Comparison of both cleaning delivery systems with treatment time: P. stutzeri and cotton wool (upper, red) and P. stutzeri and agar $2 \%$ (lower, blue); boxplots showing before and after medians, standard deviations and outliers of the different treatment times with: (b) Bacteria and cotton wool; and (c) bacteria with agar $2 \%$.

\subsection{Bacteria Monitoring}

The bacterial viability study of the bacterial solutions applied for the bio-desalination treatment after $72 \mathrm{~h}$ in the freezer to simulate the travel conditions showed a high BSR of $84.1 \%$.

The study of the microbial presence on the pavement using contact plates showed very low microbial counts. When comparing the samples taken before ( $22.3 \pm 16.77 \mathrm{CFU})$ and few days after $(33.33 \pm 20.82 \mathrm{CFU})$ the biological treatments (to allow the surfaces to dry completely) no significant 
difference was detected $(p>0.05)$. These results show that biocleaning treatments did not change the CFUs present on the granite surface.

\section{Discussion}

According to the analysis performed on the granite pavement slabs, nitrates were the main salts present on the pavement. This nitrate salt content, according to previous studies carried out on the Conxo chapel pavement (before any treatments), showed a non-homogeneous distribution over the pavement, as occurs frequently on large stone areas [8,27].

Our findings show that both traditional and biological techniques succeed in removing salt content and show a cleaner surface, but bio-desalination showed lower levels of salts and nitrates on the surface after treatment.

Ion conductivity analysis showed that even though salt absorption by traditional treatments is very high, the presence of salts on the surface of the pavement after treatment is higher compared to that after biological desalination. These results agree with those of other authors who state that it is important to measure the salts absorbed in the plasters used but also to know how the substrate salt distribution is affected because salt re-emergence can occur and produce new salt problems [6,30].

According to ion conductivity content of the surface after treatment, the best biological treatment assayed was the one with P. stutzeri and agar $2 \%$ applied for $48 \mathrm{~h}$, while the best traditional desalination method tested was cellulose applied three times for $24 \mathrm{~h}$, showing mean levels of salts remaining on the slab surface after treatments of $48.73 \mu \mathrm{S} / \mathrm{cm}$ and $126.33 \mu \mathrm{S} / \mathrm{cm}$, respectively. There is no consensus on the final salt content that a desalination process must achieve. Some authors establish a non-problematic salt content of around $100 \mathrm{ppm}$, but others consider that the desalination process should be terminated when the salt content is constant [2]. Therefore, according to our results, bio-desalination could be considered the best desalination method tested (salt content after treatment under $100 \mathrm{ppm}$ ) but salt content should be analyzed over time in order to establish if this levels remain constant.

Poultice-only controls (cotton wool or agar $2 \%$ prepared with deionized water instead of bacteria) were analyzed in order to evaluate their ability to act as desalination poultices. In fact, a reduction in surface salt content was found compared to untreated areas, but this salt reduction was in all cases smaller when compared to the areas where living bacteria were added. Our results also agree with authors who state that when adding bacteria into water-based poultices, an increase in salt-cleaning capacity is shown [19].

Semi-quantitative nitrate analysis on the treated surfaces confirmed that an important reduction was only detected on the areas treated with P. stutzeri and agar $2 \%$ for $48 \mathrm{~h}(100 \mathrm{ppm})$ and with P. stutzeri and cotton wool for $48 \mathrm{~h}(200 \mathrm{ppm})$. This colorimetric test has a sensitivity range between 0 and $500 \mathrm{ppm}$, therefore does not show values over $500 \mathrm{ppm}$ nitrate concentration. All the other treatment areas showed nitrate test results over $500 \mathrm{ppm}$. This does not mean that there has not been reduction in nitrate content in the other desalination tests, but that the level obtained was higher than the sensitivity of the analytical test used. More sensitive methods could be used in cases where detecting the exact amount of salt presents on the treated surfaces is of interest, such as ion chromatography, but they imply micro-sampling by scalpel and therefore the destructive nature of the technique should be taken into account.

Digital image analysis tools are an affordable, sustainable, non-destructive and useful set of methods, applicable to areas of various sizes (from $\mu \mathrm{m}^{2}$ to $\mathrm{m}^{2}$ ) that allow a storage and quantification of diverse elements that sometimes cannot be recognized by the naked eye $[16,26]$. Digital image analysis has been previously used as a non-contact and non-destructive technique for the detection and quantification of stone surface areas covered by algal biofilms [16], lichen colonies [31] and microbial communities [32], but to the best of our knowledge they have never been used to analyze a cleaned surface after a tested treatment.

Due to the fact that, in this particular case, a blackening of the surface was observed as a consequence of high salt content in the slab, original digital image protocols were established in order 
to use image analysis to evaluate the cleaning. Results obtained have shown that both traditional and biological methods were able to clean the surfaces, as could be seen by the naked eye. But digital imaging allows us to better evaluate, quantify relatively, and objectively compare the differences between the tested treatments. Regarding the traditional treatments tested, the one that produced the cleanest surface was that using cellulose applied three times in $24 \mathrm{~h}$ (C24), agreeing with the ion conductivity results. Regarding the biological treatments tested, the best cleaning results were shown after $48 \mathrm{~h}$ of treatment. When comparing bio-desalination using cotton wool or agar $2 \%$ as delivery systems, better cleaning results were shown with cotton wool. This difference could be due to the fact that the granite surface is very rough and the treatment contact area was higher when using cotton wool than $2 \%$ solid agar gel. Future tests should be done using warm agar gel in order to augment the contact surface, as suggested by previous studies [33,34]. The inconvenience of using cotton wool is that it retains less humidity over time, it being necessary to add water over $24 \mathrm{~h}$ to allow the bacteria to survive and denitrify. Therefore, the water input to the treated surface is higher. This augmented water intake could mobilize salts to the surface of the slab, thus explaining why the salt conductivity and nitrate presence on the surface were higher even though the surface looked cleaner.

\section{Conclusions}

An ideal standard stone desalination method does not exist, and when a monument has to be treated, complete desalination is never achievable. Therefore, it is essential to perform preliminary tests to select the best method and application conditions for the particular problem. There are different criteria that must be evaluated in order to select the best desalination method: (i) The salt extraction capacity of the tested methods; (ii) the salt content remaining on the cleaned surface after intervention over time (because salt movement and recrystallisation can happen again on the cleaned surface if the climatic conditions are favorable); and (iii) the degree of cleaning. These parameters should be analyzed because, as our results suggest, there is not always a direct relation between, salt extraction, salt content remaining on the surface after treatment, and visual cleaning.

The results obtained contribute with a novel implementation of practical biocleaning technologies for cultural heritage applications and for their use in the bio-desalination of granite surfaces. This being the first time that biocleaning has been used to remove nitrates from granite stone, and that have been compared with traditional desalination techniques. Our results show that this biological method could be a useful, efficient, non-toxic, environmental-friendly desalination alternative. The feasibility of using this treatment needs to be assessed by the conservator case-by-case.

Digital analysis tools have been successfully adapted to analyze and compare surfaces before and after desalination treatments, giving the conservator-restorer a non-destructive, sustainable and cheap new tool for analyzing diverse cleaning results.

Due to the fact that salt problems in granite pavements usually affect very large areas, future research studies should be carried out on the applicability of this bio-desalination method for such areas. Future studies should be particularly focused on: (i) Optimizing the conditions for up-scaling biomass production for the treatment of large areas contaminated with nitrates; (ii) optimizing application protocols for large areas; and (iii) optimizing the digital analysis tools for an accessible app that could allow any size surface cleaning efficiency evaluation with a mobile phone digital camera.

Supplementary Materials: The following are available online at http://www.mdpi.com/2071-1050/11/15/4227/s1, Table S1: Ion conductivity mean results of different poultices (C: Cellulose, S: Sepiolite, SP: Sepiolite and plastic film); contact times (10: $10 \mathrm{~min}, 24: 24 \mathrm{~h}, 144: 144 \mathrm{~h})$; applications $(1,2,3,4,5,6,7,8,9)$ and standard deviation.

Author Contributions: P.B.-R. and H.A.: Conceptualization and design of the experiments and methodology; P.B.-R.: Supervision of experimental procedures, formal analysis and data curation of the bio-desalination research carried out; H.A.: Experimental procedures, formal analysis and data curation of the traditional desalination research carried out; I.B.: Digital image software design, validation and analysis; P.B.-R.: Data curation in comparison with the current literature; P.B.-R., H.A. and I.B.: Writing-original draft preparation; P.B.-R. and I.B.: Writing-review and editing, visualization, supervision, project administration; P.B.-R and H.A.: Experimental funding acquisition; P.B.-R., H.A. and I.B.: Publication funding acquisition. 
Funding: This research was partially funded by CONSORCIO DE SANTIAGO, which promotes intervention studies in this building, and Vitruvian Technologies SL.

Acknowledgments: The authors wish to thank the Instituto Universitario de Restauración del Patrimonio (IRP), and the Escuela Técnca Superior de Arquitectura de Madrid for their support and wish to give special thanks to $\mathrm{M}^{\mathrm{a}}$ Teresa Doménech Carbó and Laura Osete Cortina, from the IRP Physical and chemical laboratory, for their FTIR and photometric analysis analytical support service, and to Architect Lourdes Perez Castro, responsible for the project at the Consorcio de Santiago Technical Office, for her important support, help, enthusiasm and involvement given to us for the realization of this research project.

Conflicts of Interest: The authors declare no conflicts of interest. The funders had no role in the design of the study; in the collection, analysis, or interpretation of data; in the writing of the manuscript, or in the decision to publish the results.

\section{References}

1. Charola, A.E. Salts in the deterioration of porous materials. An overview. J. Am. Inst. Conserv. 2000, 39, 327-343. [CrossRef]

2. Zornoza-Indart, A. Técnicas de desalación. In La Conservación De Los Geomateriales Utilizados En El Patrimonio; Programa Geomateriales: Madrid, Spain, 2012; pp. 143-154.

3. May, E.; Jones, M. Conservation Science. Heritage Materials; RSC Publishing: Cambridge, UK, 2016.

4. Bosch-Roig, P.; Regidor, J.L.; Estellés, R.M. Biocleaning of nitrate alterations on wall paintings by Pseudomonas stutzeri. Int. Biodeterior. Biodegrad. 2013, 84, 266-274. [CrossRef]

5. Matyšc, O.; Ottosen, L.M.; Rörig-Dalgaard, I. Desalination of salt damaged Obernkirchen sandstone by an applied DC field. Constr. Build. Mater. 2014, 71, 561-569. [CrossRef]

6. Kröner, S.; Mañas Alcaide, B.; Mas-Barberà, X. Influence of substrate pore size distribution, poultice type, and application technique on the desalination of medium-porous stones. Stud. Conserv. 2016, 61, $286-296$. [CrossRef]

7. Carretero, M.I.; Bernabé, J.M.; Galán, E. Application of sepiolite-Cellulose pastes for the removal of salts from building stones. Appl. Clay Sci. 2006, 33, 43-51. [CrossRef]

8. Auras, M. Poultices and mortars for salt contaminated masonry and stone objects. In Salt Weathering on Buildings and Stone Sculptures Copenhagen; Technical University of Denmark: Copenhagen, Denmark, 2008; pp. 197-217.

9. Pel, L.; Sawdy, A.; Voronina, V. Physical principles and efficiency of salt extraction by poulticing. J. Cult. Herit. 2010, 11, 59-67. [CrossRef]

10. Franco, B.; Gisbert, J.; Mateos, I.; Navarro, P. Deterioro de los materiales pétreos por sales: Cinética del proceso, cartografía y métodos de extracción. In Proceedings of the I Congreso GEIIC, Valencia, Spain, 25-27 November 2002; pp. 287-294. Available online: https://www.ge-iic.com/wp-content/uploads/2006/06/Franco_Belen.pdf (accessed on 1 January 2019).

11. Maureen, E.; Young, D.; Urquhart, C.M.; Lain, R. Maintenance and repair issues for stone cleaned sandstone and granite building façades. Build. Environ. 2003, 38, 1125-1131.

12. Cappitelli, F.; Toniolo, L.; Sansonetti, A.; Gulotta, D.; Ranalli, G.; Zanardini, E.; Sorlini, C. Advantages of using microbial technology over traditional chemical technology in the removal of black crusts from stone surfaces of historical monuments. Appl. Environ. Microbiol. 2007, 73, 5671-5675. [CrossRef]

13. Lubelli, B.; Van Hees, R. Desalination of masonry structures: Fine tuning of pore size distribution of poultices to substrate properties. J. Cult. Herit. 2010, 11, 10-18. [CrossRef]

14. DaSilva, E. Art, biotechnology and the culture of peace. Elect. J. Biotechnol. 2004, 7, 130-166. [CrossRef]

15. Alfano, G.; Lustrato, G.; Belli, C.; Zanardini, E.; Cappitelli, F.; Mello, E.; Sorlini, C.; Ranalli, G. The bioremoval of nitrate and sulfate alterations on artistic stonework: The case-study of Matera Cathedral after six years from the treatment. Int. Biodeterior. Biodegrad. 2011, 65, 1004-1011. [CrossRef]

16. Miller, A.Z.; Rogerio-Candelera, M.A.; Dionísio, A.; Macedo, M.F.; Saiz-Jimenez, C. Microalgae, as biodeteriogens of stone cultural heritage: Qualitative and quantitative research by non-contact techniques. In Microalgae: Biotechnology, Microbiology and Energy; Johanssen, M.N., Ed.; Nova Science Publishers: New York, NY, USA, 2011; pp. 345-358.

17. Sorlini, C.; Cappitelli, F. The application of viable bacteria for the biocleaning of cultural heritage surfaces. Coalition 2008, 15, 18-20. 
18. Webster, A.; May, E. Bioremediation of weathered-building stone surface. Trends Biotechnol. 2006, 24, $255-260$. [CrossRef] [PubMed]

19. Vucetic, S.; Ranogajec, J.; Markov, S.; Vidakovic, A.; Hirsenberger, H.; Bera, O. Development and modeling of the effective bioactive poultices for reducing the nitrate content in building materials. Constr. Build. Mat. 2017, 142, 506-513. [CrossRef]

20. Ranalli, G.; Chiavarini, M.; Guidetti, V.; Marsala, F.; Matteini, M.; Zanardini, E.; Sorlini, C. The use of microorganisms for the removal of nitrates and organic substances on artistic stoneworks. In Proceedings of the Eighth International Congress on Deterioration and Conservation of Stone, Berlin, Germany, 30 September-4 October 1996; Riederer, J., Ed.; pp. 1415-1420.

21. May, E.; Webster, A.M.; Inkpen, R.; Zamarreno, D.; Kuever, J.; Rudolph, C.; Warscheid, T.; Sorlini, C.; Cappitelli, F.; Zanardini, E.; et al. The biobrush project for bioremediation of heritage stone. In Heritage Microbiology and Science: Microbes, Monuments and Maritime Materials; May, E., Jones, M., Mitchell, J., Eds.; RSC Publishing: Cambridge, UK, 2008; pp. 76-93.

22. Romano, I.; Abbate, M.; Poli, A.; D'orazio, L. Bio-cleaning of nitrate salt efflorescence on stone samples using extremophilic bacteria. Sci. Rep. 2019, 9, 1668-1679. [CrossRef] [PubMed]

23. Soffritti, I.; D'Accolti, M.; Lanzoni, L.; Volta, A.; Bisi, M.; Mazzacane, S.; Caselli, E. The potential use of microorganisms as restorative agents: An update. Sustainability 2019, 11, 3853. [CrossRef]

24. UNE-EN 16455:2016. Conservation of Cultural Heritage-Extraction and Determination of Soluble Salts in Natural Stone and Related Materials Used in and from Cultural Heritage; AENOR: Madrid, Spain, 2016. Available online: www.une.org (accessed on 1 January 2019).

25. Wolbers, R.C. Lecture Notes for Cleaning Workshop Aqueous Materials and Methods-Dos and Don'ts. Raising Awareness on the Possibilities and Safe Boundaries of Surface Cleaning; Universidad Politécnica de Valencia: Valencia, Spain, 2014.

26. Sanmartin, P.; Chorro, E.; Vázquez-Nion, D.; Martínez-Verdú, F.M.; Prieto, B. Conversion of a digital camera into a non-contact colorimeter for use in stone cultural heritage: The application case to Spanish granites. Measurement 2014, 56, 194-202. [CrossRef]

27. García Morales, S.; Otero Ortiz de Cosca, R.; Allegue Castelos, H. Investigación Sobre El Oscurecimiento Húmedo Que Afecta Al Enlosado De La Capilla Del Cristo De Santa María De Conxo; Cuadernos técnicos; Consorcio de Santiago Oficina Técnica: Santiago de Compostela, Spain, 2016. Available online: https:/issuu.com/consorciodesantiago/ docs/conxo_oscurecimiento_humedo (accessed on 1 January 2019).

28. Muñoz-Rojas, J.; Bernal, P.; Duque, E.; Godoy, P.; Segura, A.; Ramos, J.L. Involvement of cyclopropane fatty acids in the response of Pseudomonas putida KT2440 to freeze-drying. Appl. Environ. Microbiol. 2006, 472-477. [CrossRef] [PubMed]

29. Vergès-Belmin, V.; Siedel, H. Desalination of masonries and monumental sculptures by poulticing: A review. Restor. Build. Monum. (Bauinstandsetzen und Baudenkmalpflege) 2005, 11, 391-408.

30. Sawdy, A.; Lubelli, B.; Voronina, V.; Pel, L. Optimizing the extraction of soluble salts from porous materials by poultices. Stud. Conserv. 2010, 55, 26-40. [CrossRef]

31. Gazzano, C.; Favero-longo, S.E.; Matteucci, E.; Piervittori, R. Image analysis for measuring lichen colonization and within stonework. Lichenologist 2009, 41, 299-313. [CrossRef]

32. Coutinho, M.L.; Miller, A.Z.; Gutierrez-Patricio, S.; Hernandez-Marine, M.; Gomez-Bolea, A.; Rogerio-Candelera, M.A.; Philips, A.J.L.; Jurado, V.; Saiz-Jimenez, C.; Macedo, M.F. Microbial communities on deteriorated artistic tiles from Pena National Palace (Sintra, Portugal). Int. Biodeterior. Biodegrad. 2013, 84, 322-332. [CrossRef]

33. Bosch-Roig, P.; Lustrato, G.; Zanardini, E.; Ranalli, G. Biocleaning of cultural heritage stone surfaces and frescoes: which delivery system can be the most appropriate? Ann. Microbiol. 2015, 65, 1227-1241. [CrossRef]

34. Sansonetti, A.; Casati, M.; Striova, J.; Canevali, C.; Anzani, M.; Rabbolini, A. A cleaning method based on the use of agar gels: New tests and perspectives. In Proceedings of the 12th International Congress on the Deterioration and Conservation of Stone Columbia University, New York, NY, USA, 2012.

(C) 2019 by the authors. Licensee MDPI, Basel, Switzerland. This article is an open access article distributed under the terms and conditions of the Creative Commons Attribution (CC BY) license (http://creativecommons.org/licenses/by/4.0/). 